\title{
Florabankl : a grid-based database on vascular plant distribution in the northern part of Belgium (Flanders and the Brussels Capital region)
}

\author{
Wouter Van Landuyt ${ }^{1,2}$, Leo Vanhecke ${ }^{3}$, Dimitri Brosens ${ }^{1}$
}

\author{
I Research Institute for Nature and Forest, Kliniekstraat 25, 1070, Brussels, Belgium 2 Flo. Wer, Bouchout \\ Domain, Nieuwelaan 38, 1070, Meise, Belgium 3 NBGB (National Botanic Garden of Belgium), Bouchout \\ Domain, Nieuwelaan 38, 1860, Meise, Belgium
}

Corresponding author: Wouter Van Landuyt (wouter.vanlanduyt@inbo.be)

Academic editor: Vishwas Chavan | Received 6 February 2012 | Accepted 15 May 2012 | Published 16 May 2012

Citation: Van Landuyt W, Vanhecke L, Brosens D (2012) Florabank1: a grid-based database on vascular plant distribution in the northern part of Belgium (Flanders and the Brussels Capital region). PhytoKeys 12: 59-67. doi: 10.3897/phytokeys.12.2849

\begin{abstract}
Florabank1 is a database that contains distributional data on the wild flora (indigenous species, archeophytes and naturalised aliens) of Flanders and the Brussels Capital Region. It holds about 3 million records of vascular plants, dating from 1800 till present. Furthermore, it includes ecological data on vascular plant species, redlist category information, Ellenberg values, legal status, global distribution, seed bank etc. The database is an initiative of "Flo.Wer" (www.plantenwerkgroep.be), the Research Institute for Nature and Forest (INBO: www.inbo.be) and the National Botanic Garden of Belgium (www.br.fgov.be). Florabank aims at centralizing botanical distribution data gathered by both professional and amateur botanists and to make these data available to the benefit of nature conservation, policy and scientific research.

The occurrence data contained in Florabank1 are extracted from checklists, literature and herbarium specimen information. Of survey lists, the locality name (verbatimLocality), species name, observation date and IFBL square code, the grid system used for plant mapping in Belgium (Van Rompaey 1943), is recorded. For records dating from the period 1972-2004 all pertinent botanical journals dealing with Belgian flora were systematically screened. Analysis of herbarium specimens in the collection of the $\mathrm{Na}-$ tional Botanic Garden of Belgium, the University of Ghent and the University of Liège provided interesting distribution knowledge concerning rare species, this information is also included in Florabank1. The data recorded before 1972 is available through the Belgian GBIF node (http://www.gbif.org/ dataset/940821c0-3269-11df-855a-b8a03c50a862), not through FLORABANK1, to avoid duplication of information. A dedicated portal providing access to all published Belgian IFBL records at this moment is available at: http://projects.biodiversity.be/ifbl

All data in Florabank1 is georeferenced. Every record holds the decimal centroid coordinates of the IFBL square containing the observation. The uncertainty radius is the smallest circle possible covering the

Copyright Wouter Van Landuyt et al. This is an open access article distributed under the terms of the Creative Commons Attribution License 3.0 (CC-BY), which permits unrestricted use, distribution, and reproduction in any medium, provided the original author and source are credited.
\end{abstract}


whole IFBL square, which can measure $1 \mathrm{Km}^{2}$ or $4 \mathrm{Km}^{2}$. Florabank is a work in progress and new occurrences are added as they become available; the dataset will be updated through GBIF on a regularly base.

\section{Keywords}

Tracheophyta, grid mapping, flora, indigenous species, archeophytes, naturalised aliens

\section{Data published through}

GBIF: http://data.inbo.be/ipt/resource.do?r=florabank1-occurrences

\section{Taxonomic coverage}

Note: The taxonomic reference for the florabank1 database is the 1998 edition of the Belgian Flora by Lambinon et al. 1998.

\section{General taxonomic coverage description}

The coverage (figure 1) of this database spans the Phylum Tracheophyta or vascular plants. The highest number of records are from the Magnoliopsida (76.48\%) followed by Monocotyledones (20.92\%), Filicopsida (1.44\%), Sphenopsida $(0.97 \%)$ Coniferopsida $(0.13 \%)$ and Lycopsida $(0.03 \%)$. Ginkgopsids are within the scope of Florabank, but do not occur within the geographical scope of the database.

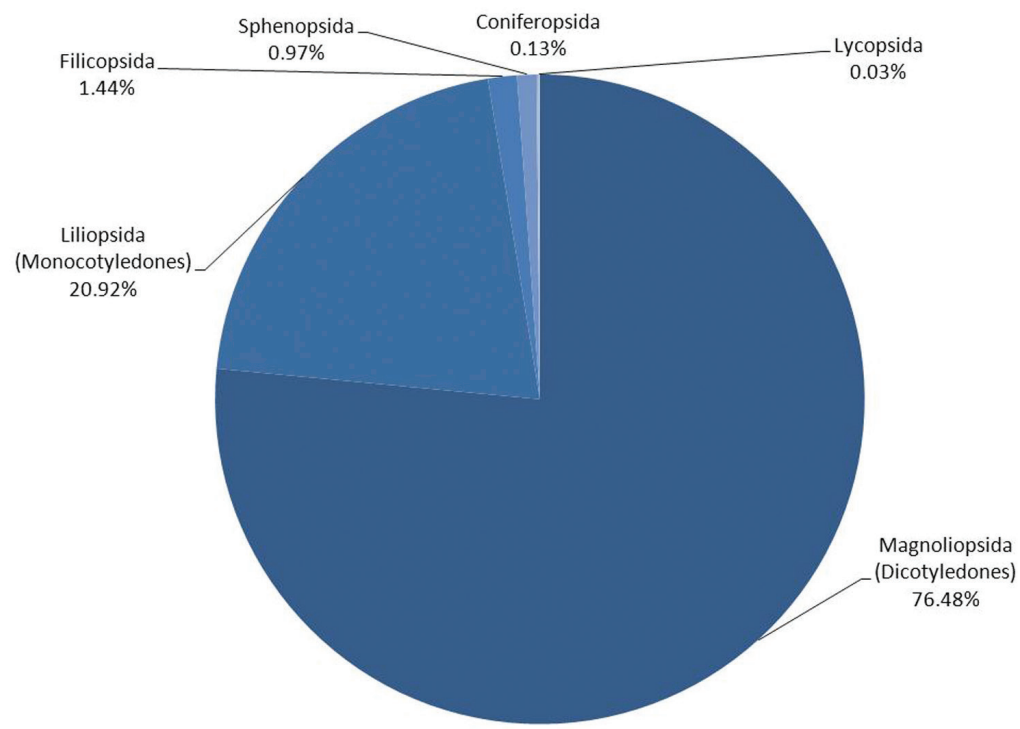

Figure I. Taxonomic coverage of Florabank1 


\section{Taxonomic ranks}

Phylum: Tracheophyta

Class: Coniferopsida, Filicopsida, Ginkgopsida, Liliopsida (Monocotyledones), Lycopsida, Magnoliopsida (Dicotyledones), Sphenopsida

Order: Pinales, Taxales, Filicales, Marsileales, Ophioglossales, Osmundales, Salviniales, Ginkgoales, Alismatales, Arales, Commelinales, Cyperales, Hydrocharitales, Juncales, Liliales, Najadales, Orchidales, Poales, Pontederiales, Typhales, Typhales, Zingiberales, Isoetales, Lycopodiales, Selaginellales, Apiales, Apiales, Aristolochiales, Asterales, Callitrichales, Campanulales, Capparales, Caryophyllales, Celastrales, Cornales, Cucurbitales, Dipsacales, Elaeagnales, Ericales, Euphorbiales, Fabales, Gentianales, Geraniales, Haloragales, Haloragales, Hamamelidales, Juglandales, Lamiales, Linales, Loganiales, Magnoliales, Malvales, Myricales, Myrtales, Nymphaeales, Oleales, Paeoniales, Papaverales, Piperales, Plantaginales, Plumbaginales, Polemoniales, Polygalales, Polygonales, Primulales, Ranunculales, Rhamnales, Rosales, Rubiales, Rutales, Salicales, Santalales, Sapindales, Sarraceniales, Saxifragales, Scrophulariales, Theales, Thymelaeales, Urticales, Violales, Violales, Gymnospermae, Equisetales

Family: Araucariaceae, Cupressaceae, Pinaceae, Taxodiaceae, Taxaceae, Adiantaceae, Aspleniaceae, Blechnaceae, Dennstaedtiaceae, Dryopteridaceae, Hymenophyllaceae, Polypodiaceae, Thelypteridaceae, Woodsiaceae, Marsileaceae, Ophioglossaceae, Osmundaceae, Azollaceae, Salviniaceae, Ginkgoaceae, Alismataceae, Butomaceae, Araceae, Lemnaceae, Commelinaceae, Cyperaceae, Hydrocharitaceae, Juncaceae, Agavaceae, Alliaceae, Amaryllidaceae, Dioscoreaceae, Iridaceae, Liliaceae, Aponogetonaceae, Juncaginaceae, Najadaceae, Potamogetonaceae, Ruppiaceae, Scheuchzeriaceae, Zannichelliaceae, Zosteraceae, Orchidaceae, Poaceae, Pontederiaceae, Sparganiaceae, Typhaceae, Cannaceae, Isoetaceae, Lycopodiaceae, Selaginellaceae, Apiaceae, Araliaceae, Aristolochiaceae, Asteraceae, Callitrichaceae, Campanulaceae, Lobeliaceae, Brassicaceae, Capparaceae, Resedaceae, Aizoaceae, Amaranthaceae, Caryophyllaceae, Chenopodiaceae, Molluginaceae, Nyctaginaceae, Phytolaccaceae, Portulacaceae, Aquifoliaceae, Celastraceae, Cornaceae, Cucurbitaceae, Adoxaceae, Caprifoliaceae, Dipsacaceae, Valerianaceae, Elaeagnaceae, Actinidiaceae, Clethraceae, Empetraceae, Ericaceae, Monotropaceae, Pyrolaceae, Buxaceae, Euphorbiaceae, Caesalpiniaceae, Fabaceae, Betulaceae, Fagaceae, Apocynaceae, Asclepiadaceae, Gentianaceae, Balsaminaceae, Geraniaceae, Limnanthaceae, Oxalidaceae, Tropaeolaceae, Gunneraceae, Haloragaceae, Hippuridaceae, Hamamelidaceae, Platanaceae, Juglandaceae, Boraginaceae, Lamiaceae, Verbenaceae, Linaceae, Buddlejaceae, Calycanthaceae, Magnoliaceae, Malvaceae, Tiliaceae, Myricaceae, Lythraceae, Onagraceae, Trapaceae, Cabombaceae, Ceratophyllaceae, Nymphaeaceae, Oleaceae, Paeoniaceae, Fumariaceae, Papaveraceae, Saururaceae, Plantaginaceae, Plumbaginaceae, Convolvulaceae, Cuscutaceae, Hydrophyllaceae, Menyanthaceae, Polemoniaceae, Solanaceae, Polygalaceae, Polygonaceae, Primulaceae, Berberidaceae, Menispermaceae, Ranunculaceae, Rhamnaceae, Vitaceae, 
Amygdalaceae, Malaceae, Rosaceae, Rubiaceae, Anacardiaceae, Rutaceae, Simaroubaceae, Zygophyllaceae, Salicaceae, Loranthaceae, Santalaceae, Aceraceae, Hippocastanaceae, Sapindaceae, Staphyleaceae, Droseraceae, Crassulaceae, Grossulariaceae, Hydrangeaceae, Saxifragaceae, Bignoniaceae, Globulariaceae, Lentibulariaceae, Martyniaceae, Orobanchaceae, Pedaliaceae, Scrophulariaceae, Elatinaceae, Hypericaceae, Thymelaeaceae, Cannabaceae, Moraceae, Ulmaceae, Urticaceae, Begoniaceae, Cistaceae, Frankeniaceae, Loasaceae, Passifloraceae, Tamaricaceae, Violaceae, Ephedraceae, Equisetaceae

Common names: conifers, ferns, ginkgos, monocots, lycopods, dicots, horsetails

\section{Spatial coverage}

General spatial coverage: Florabank deals with distribution data of the wild flora of Flanders and the Brussels Capital Region (Federal states of the Kingdom of Belgium). Florabank covers an area of $13.682 \mathrm{~km}^{2}$. Flanders has a temperate maritime climate influenced by the North Sea and the Atlantic Ocean, with relatively moderate summers and mild winters. Flanders is the northern part of Belgium. The two main geographical regions of Flanders are the Yser basin, in the North-West and the central plain. Flanders is divided in 6 ecoregions (Dunes district; Kempens district; Loam district; River Maas; Polder district, Sand and Loam district). The Brussels Capital region is a small region $\left(162 \mathrm{~km}^{2}\right)$ surrounded Flanders and is entirely situated in the Loam district. The majority of this region is highly urbanized and only the southern part is occupied by a large beech forest.

Coordinates: $50^{\circ} 37^{\prime} 12^{\prime \prime} \mathrm{N}$ and $51^{\circ} 29^{\prime} 24^{\prime \prime} \mathrm{N}$ Latitude; $2^{\circ} 31^{\prime} 12^{\prime \prime} \mathrm{E}$ and $6^{\circ} 12^{\prime} 0^{\prime \prime} \mathrm{E}$ Longitude

\section{Temporal coverage}

1800-2011.

\section{Sampling Methods}

The spatial coverage of the territory has evolved through time. The data from the period before 1939 pertains mostly to herbarium specimens and reflects only part of the vascular plant composition of the region. From 1939 onwards most observations are collected using a standardized protocol based on the methodology used for the Atlas of the flora of Belgium and Luxemburg (Van Rompaey and Delvosalle 1972). The atlas area is covered by a grid of $4 \times 4 \mathrm{Km}$ squares, which is further subdivided into $1 \times 1$ $\mathrm{Km}$ squares. All species observed during a visit to a grid cell of $1 \mathrm{~km}^{2}$ were recorded without distinguishing between common or rare species. In each $4 \times 4 \mathrm{~km}$ square, 
more than one $1 \mathrm{~km}^{2}$ squares were surveyed. The inventories dating from the period 1939-1971 fed the Atlas of the flora of Belgium and Luxemburg (Van Rompaey and Delvosalle 1972) (figure 2), while those from 1972-2004 served to produce that by Van Landuyt et al. (2006) (figure 3). During the first period (figure 2) only one survey of $1 \mathrm{~km}^{2}$ in each grid of $4 \times 4 \mathrm{~km}$ was required, during the second period we attempted to obtain data from at least four $1 \mathrm{~km}^{2}$ grids in each grid of 4x4 km. From 2005 onwards we continued to gather data using the same protocol.

\section{Quality Control}

All records are validated before they are added to Florabank. The basic reference for quality control is the Belgian atlas (Van Rompaey and Delvosalle 1972). New data to be entered into the database are first submitted to a preliminary, automatic control. Observations pertaining to common species which were previously validated to occur in the neighbouring grid cells of $4 \times 4 \mathrm{~km}$ squares over the last 35 years are automatically validated. Observations of species that are considered rare, or common species that have not been recorded in the neighbouring grid cells since 35 years are subjected to a manual control by experts. If the record concerns a location validated by other sources (e.g. recent herbarium specimens, peer reviewed papers) it is validated by the managers of the database, if not the observers can be asked to provide extra proof of their observation (e.g. herbarium specimens or photographs). Once an observation is validated (automatically or by the database manager) it can be considered for the validation of new observations.

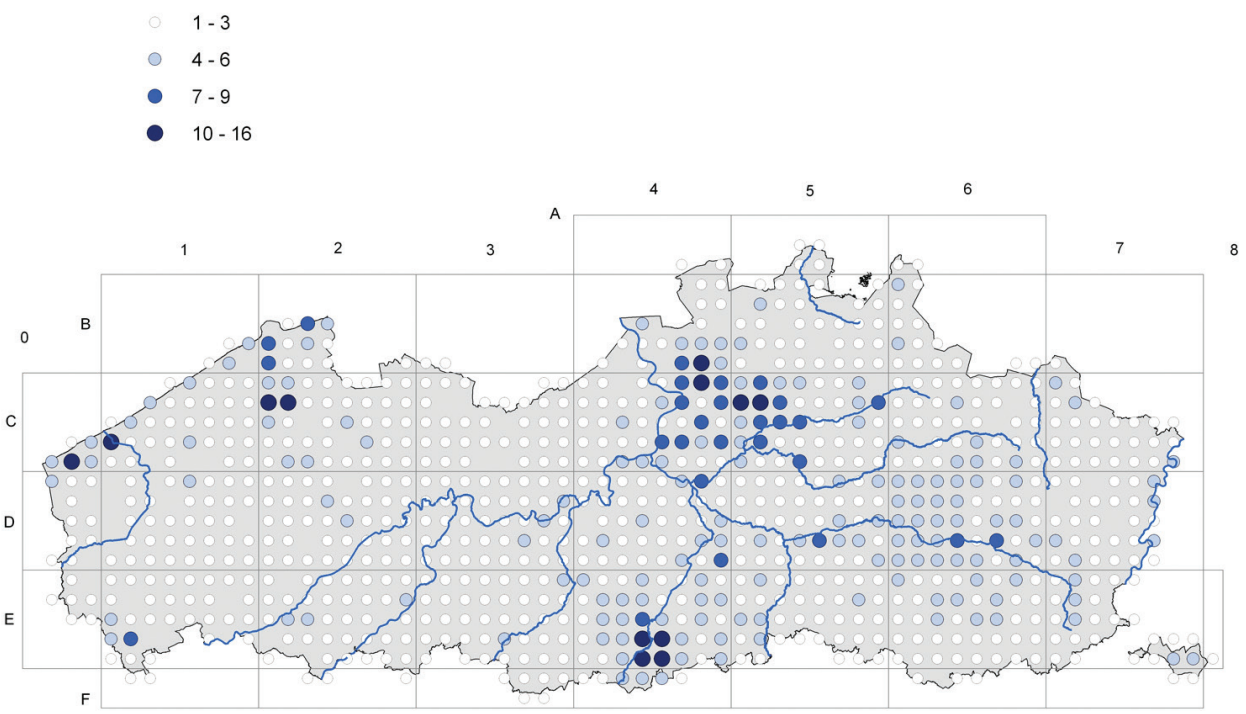

Figure 2. Number of prospected $1 \mathrm{~km}^{2}$ grids in each grid of $4 \times 4 \mathrm{~km}$ for the period 1939-1971. A $1 \mathrm{~km}^{2}$ grid cell is considered as prospected if at least 90 species have been recorded. 


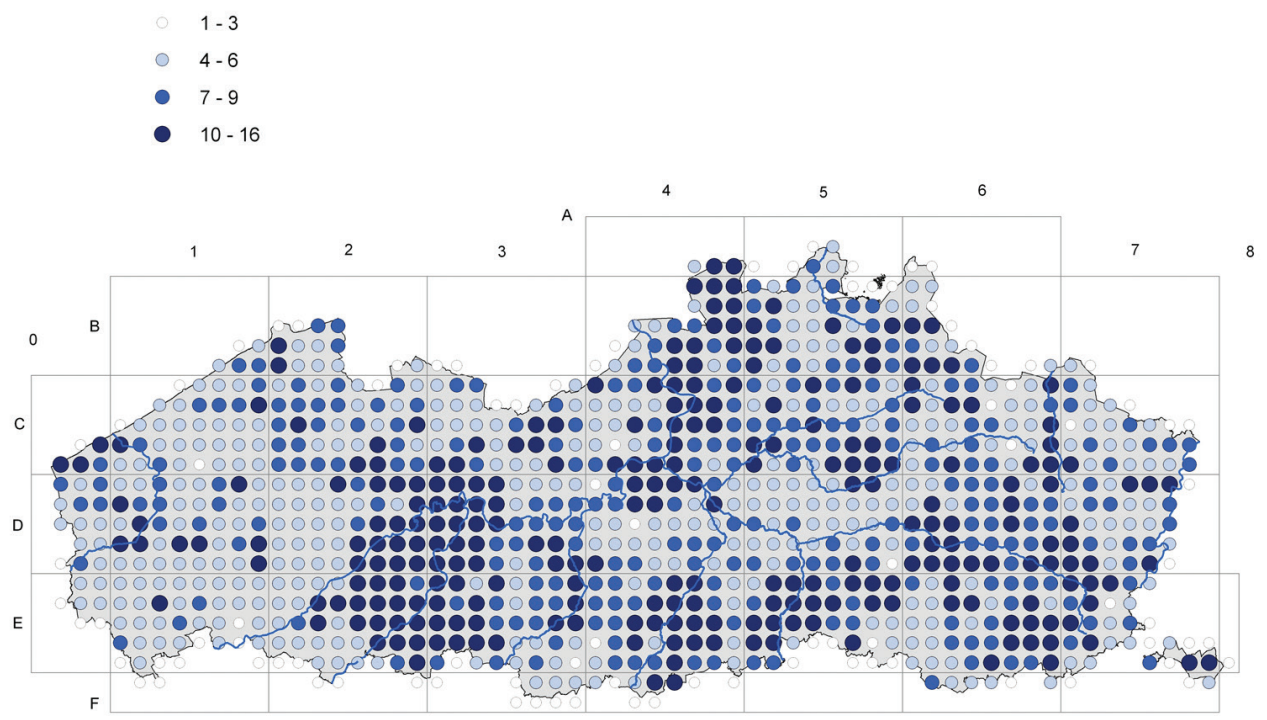

Figure 3. Number of prospected $1 \mathrm{~km}^{2}$ grids in each grid of $4 \times 4 \mathrm{~km}$ for the period $1972-2004$. A $1 \mathrm{~km}^{2}$ grid cell is considered as prospected if at least 90 species have been recorded.

\section{Datasets}

\section{Dataset description}

The Florabank1 dataset is a custom made SQL view of the Florabank database hosted in the Research Institute for Nature and Forest. The view shows only those data that are accepted for publication in the Darwin Core standard. Fields given are: occurenceID, modified, language, institutionCode, collectionCode, basisOfRecord, catalogNumber, recordedBy, occurrenceDetails, eventDate, country, verbatimLocality, verbatimCoordinates, verbatimCoordinatesystem, decimalLatitude, decimalLongitude, geodeticDatum, coordinateUncertaintyInMeters, scientificName, originalNameUsage, taxonRank, verbatimTaxonrank and nomenclaturalCode.

Object name: Darwin Core Archive Florabank1: a grid-based database on vascular plant distribution in the northern part of Belgium

Character encoding: UTF-8

Format name: Darwin Core Archive format

Format version: 1.0

Distribution: http://data.inbo.be/ipt/archive.do? r=florabank1-occurrences

Publication date of data: 2011-03-25

Language: Dutch

Licenses of use: This work is licensed under a Creative Commons Attribution-NonCommercial-NoDerivs 3.0 Unported License. 


\author{
Metadata language: English \\ Date of metadata creation: 2011-03-25 \\ Hierarchy level: Dataset
}

\title{
References
}

\section{1) References cited within the metadata}

Van Rompaey E (1943) Cartes Floristiques, Bulletin de la Société Royale de Botanique de Belgique 75: 48-56.

Van Rompaey E, Delvosalle L (1972) Atlas de la flore belge et luxembourgeoise: ptéridophytes et spermatophytes $=$ Atlas van de belgische en luxemburgse flora: pteridofyten en spermatofyten. Nationale Plantentuin van België: Brussel. 282 pp.

Lambinon J, De Langhe J-E, Delvosalle L, Duvigneaud J (1998) Flora of Belgium, Luxembourg, Northern France and neighboring areas (pteridofyten and spermatofyten). 3rd Edition. National Botanic Garden of Belgium: Meise. ISBN 90-72619-23-4. CXXIII, 1091 pp. [in Dutch]

Van Landuyt W, Hoste I, Vanhecke L, Van den Bremt P, Vercruysse E, De Beer D (2006) Atlas van de Flora van Vlaanderen en het Brussels Gewest. Instituut voor natuur- en bosonderzoek, Nationale Plantentuin van België \& Flo. Wer, Brussel.

\section{2) References to literature used to build the dataset}

Several Belgian scientific journals (Dumortiera, Bulletin de la Société Royale de Botanique de Belgique- Belgian Journal of Botany, Natura Mosana, Mémoires de la Société Royale de Botanique de Belgique, Natura, Les Naturalistes Belges, Natura Limburg, Adoxa, Biologisch Jaarboek Dodonnea, Jaarbulletin van de Vrienden van Heverleebos, Meerdaalwoud and Wielewaal) were scanned for relevant observations from the Flemish region and the Brussels Capital Region. All the volumes from 1972 to date were checked for relevant occurrences. These occurrences were added to Florabank.

Adoxa [Periodicals] (1993-2000), vol. 1-25. ISSN 0779-7524

Belgian Journal of Botany. [Periodicals] (1990-1999), vol. 123-132. ISSN 0778-4031, vol. 122-142.

Biologisch Jaarboek. Dodonaea [Periodicals] (1972-1987), vol 40-55.

Bulletin de la Société royale de botanique de Belgique = Bulletin van de Koninklijke Belgische botanische vereniging [Periodicals] (1972-1989), vol. 105-122. ISSN 0037-9557

Dumortiera [Periodicals] (1975-2011), vol. 1-99. ISSN 0251-1134

Jaarbulletin van de Vrienden van Heverleebos en Meerdaalwoud [Periodicals] (1970-1998).

Les Naturalistes Belges [Periodicals] (1972-1999), vol. 53-80. ISSN 0028-0801

Natura [Periodicals] (1972-2000), vol. 67-180. ISSN 0028-0631

Natura Mosana [Periodicals] (1973-1999), vol. 26-52. ISSN 0028-0666

Wielewaal [Periodicals] (1972-2001), vol. 38-67. ISSN 0043-5260 


\section{3) Publications based on this dataset}

Honnay O, Piessens K, Van Landuyt W, Hermy M, Gulinck H (2003) Satellite based land use and landscape complexity indices as predictors for regional plant species diversity. Landscape and Urban Planning, 63: 241-250. doi: 10.1016/S0169-2046(02)00194-9

Hoste I, Van Landuyt W, Verloove F (2006) Landschap en flora in beweging, 19de en 20ste eeuw. In: Van Landuyt W et al. (Ed) (2006) Atlas van de flora van Vlaanderen en het Brussels Gewest, 45-67.

Louette G, Adriaens D, Adriaens P, Anselin A, Devos K, Sannen K, Van Landuyt W, Paelinckx D, Hoffmann M (2011) Bridging the gap between the Natura 2000 regional conservation status and local conservation objectives. Journal for Nature Conservation (September 2011), 19 (4): 224-235. doi: 10.1016/j.jnc.2011.02.001

Maes D, Bauwens D, De Bruyn L, Anselin A, Vermeersch G, Van Landuyt W, De Knijf G, Gilbert M (2005) Species richness coincidence: conservation strategies based on predictive modelling. Biodiversity and Conservation (2005) 14: 1345-1364. doi: 10.1007/s10531004-9662-x

Schneiders A, Van Daele T, Van Landuyt W, Van Reeth W (2012) Biodiversity and ecosystem services: Complementary approaches for ecosystem management? Ecological Indicators, 21: 123-133. doi: 10.1016/j.ecolind.2011.06.021

Vanhecke L, Hoste I (2006) Met vallen en opstaan: het verhaal van de tweede kartering, 19722004. In: Van Landuyt W et al. (Ed) (2006) Atlas van de flora van Vlaanderen en het Brussels Gewest, 14-31.

Van Landuyt W, Vanhecke L, Hoste I (2006) Rode Lijst van de vaatplanten van Vlaanderen en het Brussels Hoofdstedelijk Gewest. In: Van Landuyt W et al. (Ed) (2006) Atlas van de flora van Vlaanderen en het Brussels Gewest, 69-81.

Van Landuyt W, Vanhecke L, Hoste I (2006) Verzameling en verwerking van de basisgegevens. In: Van Landuyt W et al. (Ed) (2006) Atlas van de flora van Vlaanderen en het Brussels Gewest, 33-42.

Van Landuyt W, Hoste I, Vanhecke L, Van den Bremt P, Vercruysse E, De Beer D (2006) Atlas van de Flora van Vlaanderen en het Brussels Gewest. Instituut voor natuur- en bosonderzoek, Nationale Plantentuin van België \& Flo. Wer, Brussel.

Van Landuyt W, Hoste I, Vanhecke L (2007) Evolution générale de la flora de Flandre (Belgique) entre 1939-1971 et 1972-2004: évaluation des changements en tenant compte de l'intensité d'inventaire. L.A.S.E.R., Actes du colloque Geoflore 2007, 2007, 119-123.

Van Landuyt W, Vanhecke L, Hoste I, Hendrickx F, Bauwens D (2008) Changes in the distribution area of vascular plants in Flanders (northern Belgium): eutrophication as a major driving force. Biodiversity and Conservation, 17: 3045-3060. doi: 10.1007/s10531-0089415-3

Van Landuyt W, de Beer D (2009) Planten. In: Beckers K et al. (Ed) (2009) Een gericht natuurbeleid voor de prioritaire soorten in de provincie Antwerpen, 25-64.

Van Landuyt W (2009) Measuring invasive speed of alien plant species using data from a general mapping program in the north of Belgium. Book of abstracts, 2nd European Congres of Conservation Biology. Czech University of Life Sciences, Faculty of Environmental Science. 147. 
Van Landuyt W, Vanhecke L, Hoste I, Bauwens D (2011) Do the distribution patterns of vascular plant species correspond to biogeographical classifications based on environmental data? A case study from northern Belgium. Landscape and Urban Planning, 99: 93-103. doi: 10.1016/j.landurbplan.2010.08.020 